\title{
THE ROLE OF SPATIAL INFORMATION SYSTEMS IN DECISION-MAKING PROCESSES REGARDING INVESTMENT SITE SELECTION
}

\author{
Monika Siejka, PhD \\ Department of Land Surveying, \\ University of Agriculture in Krakow \\ e-mail:rmwiech@cyf-kr.edu.pl
}

\begin{abstract}
One of the main tasks of real estate management is making decisions concerning the location of investments. Taking into consideration the fact that any investment affects, directly or indirectly, the economic development of a commune, it has a significant impact on the local real estate market. Investments that have a negative impact on the environment can contribute to a reduction in the activity of the local real estate market. Upon performing tasks related to the economic development of a region and to an increase in the inhabitants' quality of life, the activity of the local real estate market increases. The paper presents the role of spatial information systems as a source of data used in decision-making processes related to local investment site selection.

Currently, there are spatial information systems functioning as a platform for multi-level information systems on real estate and GIS, on local, regional, national and international markets. In this way, the resources of spatial information are available to all institutions, natural and legal persons. As a result, the acquisition of a series of data can take place at any time and at no cost.
\end{abstract}

Key words: Infrastructure for Spatial Information, investments, location, real estate.

JEL Classification: $Q 01, Q 15$.

Citation: Siejka M., 2017, The Role of Spatial Information Systems in Decision-Making Processes Regarding Investment Site Selection, Real Estate Management and Valuation, vol. 25, no. 3, pp. 62-72.

DOI: 10.1515/remav-2017-0023

\section{Introduction}

The desired state in real estate management is to achieve sustainable development, e.g., by the optimal location of public investments. This obligation is imposed, among others, by the provisions of the World Conservation Strategy elaborated by the International Union for Conservation of Nature and Natural Resources. Poland, as a full member of the EU, is obliged to implement the rules in force in the Member States. In the field of real estate management, there are guidelines for UN/ECE land management developed by a group of experts, i.e. Meeting of Officials on Land Administration (MOLA). The main task of MOLA was to promote land management in countries where the building of a market economy had only just started. The indicated guidelines define land management as a process of creation, storage and dissemination of information about the area, including the status of rights (ownership, use) as well as other forms of area management. They include, among others: the acquisition of land by buying or expropriating in order to locate investments of a public character and supra-local range. The carrying out of socio-economic activities is given as the primary objective of land management. The task of these actions is to follow the principles of land management, taking into account the equitable sharing of benefits arising from it. The land management system includes, among others: strengthening rights to land, creation and 
implementation of spatial development plans taking into account sustainable development of both urban and rural areas, and the sustainable management of environmental resources (Wilkowski et al., 2006). The guidelines clearly indicate that the sustainable management of the environment's resources is reflected in real estate management in the fields of environmental protection, environmental pollution and land reclamation. Both environmental protection and pollution are aspects that determine the size of the financial investment which generates the need for reclamation. In this situation, it is important to carry out research in order to develop a methodology for choosing the location of public purpose investments. Airports, railroads, public roads (especially motorways, ring roads of cities, highways), municipal waste disposal plants, cemeteries, sports facilities, hospitals, schools, etc. can be specified, inter alia, as public purpose investments. Investments related to the location of objects such as wind, nuclear or coal power plants, relay masts (cellular signaling networks, television), industrial plants, etc. also affect the respect for the principle of sustainable development (SIEJKA 2015).

Indicating the location of the above-mentioned investments is associated with the consideration of many factors. These factors can be classified into three basic groups. The first group will represent the factors determining the legal and technical conditions related to the given investment. The second group contains the socio-economic factors, and the third one - factors related to environmental protection. The presented principles indicate that the methodology of investment location selection should, in its assumptions, take multi-criteria analysis into account (SIEJKA 2015, 2016).

\section{Spatial information systems}

Carrying out an analysis associated with indicating the location of an investment requires obtaining information including, within its scope, various topics of spatial data. These are surveying, geographic, hydrographic, geological, environmental, social data, etc. The presented thematic scope of the data is a part of the Infrastructure for Spatial Information (INSPIRE 2007). The construction of the infrastructure for the spatial information platform significantly contributed to facilitating the access to products and services based on spatial data collected at different levels of administration. The turning point in the development of spatial data was the INSPIRE Directive (2007) and the Act on infrastructure for spatial information, passed three years later (Act 2010). These regulations defined the thematic scope of necessary data and pledged to create a coherent platform of Infrastructure for Spatial Information (ISI). The aforementioned INSPIRE Directive defines ISI as collections of spatial data described by metadata, as well as the connected services, technical measures, processes and procedures used and shared by the bodies creating this structure. According to the quoted definition, the primary purpose of ISI is to facilitate access to spatial data in order to carry out tasks in the field of real estate management. The construction and development of the ISI have resulted in it functioning today as a platform of multi-level information systems on real estate and GIS, on local, regional, national and international markets. In this way, the spatial information resources functioning within the ISI are available to all institutions, natural or legal persons (BIEDA et al. 2015; Siejka 2015).

With the development of computer technology, the active spatial databases are made available via web services. Article 12 section 1 (Act 2010) guarantees their universality and that they are free of charge. The universality of the Internet makes it possible to acquire the necessary information about properties at any time and place. Limitation of universal access to the collections and services contained in the public records concerns classified data. According to Article 11 paragraph 2, classified data are: data on the activities of the judiciary and tax authorities, public statistics, environmental protection, protection of personal data, intellectual property rights and economic activity.

In the framework of the implementation of tasks arising from the referred Act on the infrastructure for spatial information, bodies keeping the public registers are obliged to provide information contained therein. Figure 1 shows the mapping services for the city of Krakow available on the platform of Malopolska Spatial Information System (MSIP).

In the MSIP system, nine map services addressed to different groups of users were created. The user decides on the type of the base map. This can be a map of the administrative division or an orthophotomap. The planning and urban space service includes a range of data used by surveyors, real estate appraisers, real estate agents, property managers, developers and other professionals 
related to the real estate market. The map for architects and planners is a service containing basic information related to spatial planning. Inhabitants' portal is a service containing information relevant to the residents and owners of properties located within a city. Apart from the basic data on the land registry and spatial planning, there is also information of an administrative and social character. Services such as: environmental protection, noise maps, greenery management and MonitAir provide information about the level of pollution in the city, protected areas and taken decisions and preventive measures intended to improve the quality of the environment in the city. Historical Maps is a service presenting preserved, historic maps of the city of Krakow, so that it is possible to follow the directions of its development. The last service is a collective composition of maps. This service combines information contained in all of the above-mentioned services. Jest It, on the other hand, is dedicated to users who need information beyond the scope of a single service. Examples of information available within the selected services have been shown in Figures 2 and 3.

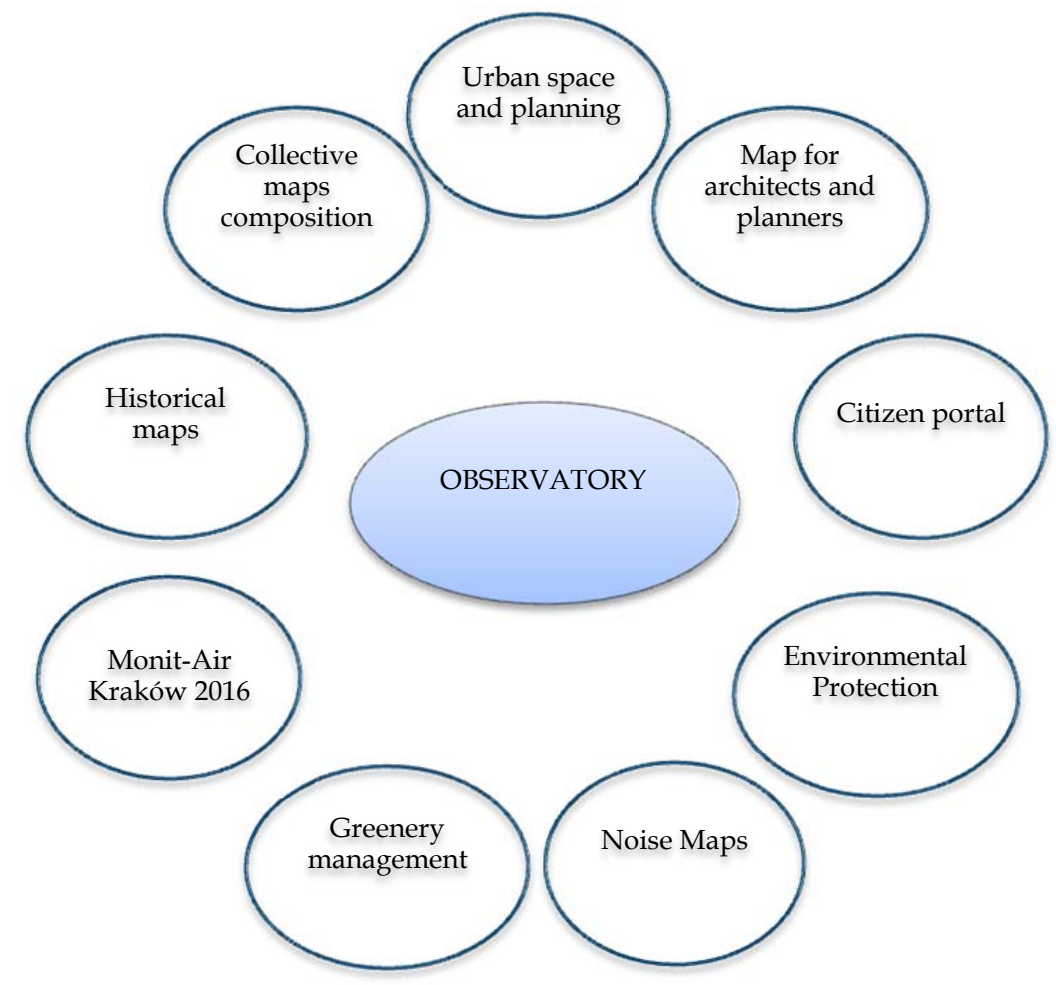

Fig. 1. Mapping services available within the MSIP portal for the city of Krakow. Source: own research based on www.msip.um.krakow.pl/obserwatorium

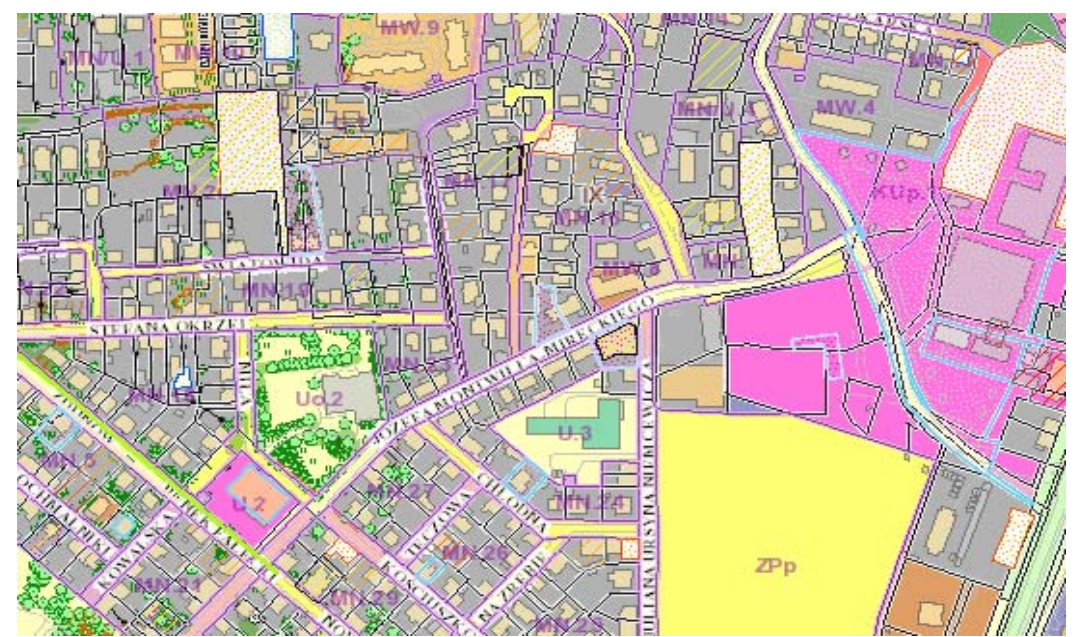

Fig. 2. Fragment of the land and buildings registry map with the contours of the spatial development plans, land development and structure of the possession of land, scale 1:5000. Source: own research based on www.msip.um.krakow.pl/obserwatorium 


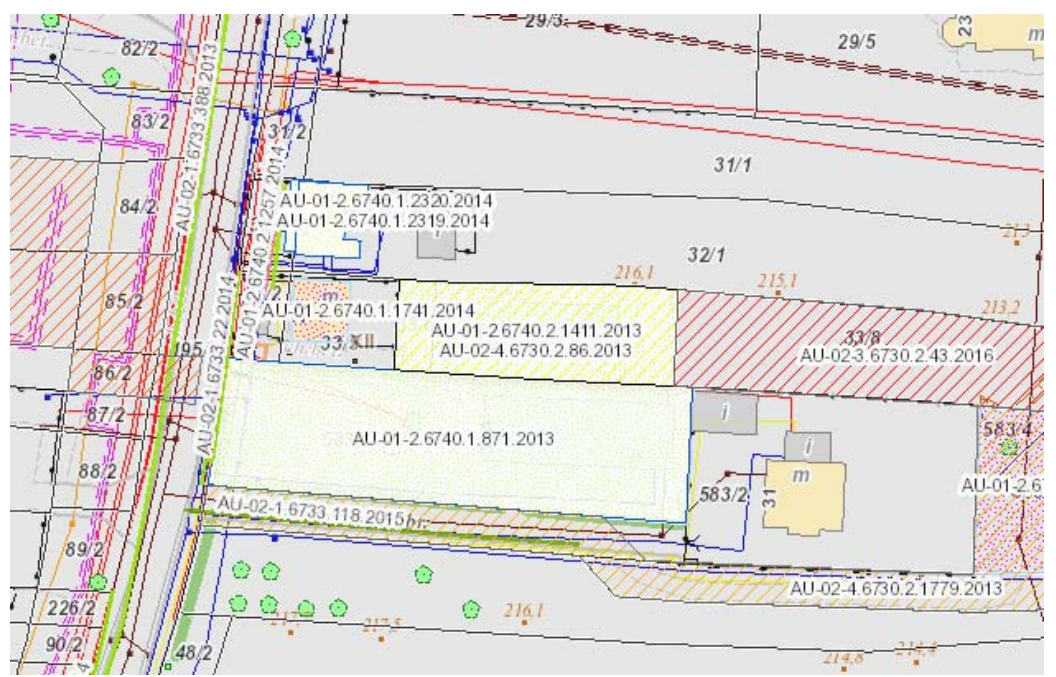

Fig. 3. Fragment of the land and buildings registry map for areas with decisions on building conditions or building permits, land development, and the utilities network, scale 1:1000. Source: own research based on www.msip.um.krakow.pl/obserwatorium

\section{The area and method of research}

The mapping services available within the ISI contain data which are necessary to carry out the analysis regarding the indication of the location of investments. In order to conduct research on the completeness of information available within the ISI system, five types of investments were indicated. Investments of a residential character - $\mathrm{R}$ (residential single-family and multi-family buildings), commercial - C (office buildings, hotels, shopping malls, etc.), public utility buildings PS (sports facilities, parks, hospitals, schools, etc.), communication infrastructure - CI (airports, railways, public roads, etc.), and investments of an industrial nature - I (industrial plants, relay masts, power plants, etc.). Choosing a location for the given investment should be preceded by the determination of requirements that must be met, as well as the effects of its implementation on the environment. The requirements are related to legal, technical and economic conditions. The effects may relate to social (improvement of social conditions, increase in employment, health care etc.) and environmental (protection of air, water, soil, noise, protection of environmentally valuable areas, protection of residential areas, agricultural, etc.) criteria. The basic spatial information available within the MSIP is shown in Table 1.

Table 1

The scope of data available within the MSIP

\begin{tabular}{|c|c|c|c|c|c|c|}
\hline \multirow{2}{*}{$\begin{array}{c}\text { Type of } \\
\text { information }\end{array}$} & \multirow{2}{*}{ Scope of information } & \multicolumn{5}{|c|}{ Type of investment } \\
\hline & & $\mathbf{R}$ & $\mathrm{C}$ & PS & CI & I \\
\hline \multirow[t]{6}{*}{ legal } & local spatial development plans & + & + & + & + & + \\
\hline & $\begin{array}{l}\text { studies of conditions and } \\
\text { directions of spatial development }\end{array}$ & + & + & + & + & + \\
\hline & $\begin{array}{l}\text { decisions - building permit / } \\
\text { renovation / modernization }\end{array}$ & + & + & + & + & + \\
\hline & ownership & + & + & + & + & + \\
\hline & perpetual usufruct & + & + & + & + & + \\
\hline & structure of land possession & + & + & + & + & + \\
\hline \multirow[t]{7}{*}{ technical } & area of the plot & + & + & + & + & + \\
\hline & configuration of borders & + & + & + & + & + \\
\hline & infrastructural networks & + & + & + & + & + \\
\hline & land development & + & + & + & + & + \\
\hline & communication accessibility & + & + & + & + & + \\
\hline & type of land use / land class & + & + & + & + & + \\
\hline & hydrogeological conditions & + & + & + & + & + \\
\hline
\end{tabular}




\begin{tabular}{|c|c|c|c|c|c|c|}
\hline \multirow[t]{3}{*}{ economic } & average transaction prices & + & + & + & + & + \\
\hline & $\begin{array}{l}\text { the average areas of the sold } \\
\text { properties }\end{array}$ & + & + & + & + & + \\
\hline & rental rates & + & + & & + & \\
\hline \multirow[t]{3}{*}{ social } & $\begin{array}{l}\text { access to public / societal / social } \\
\text { services }\end{array}$ & + & & & & \\
\hline & access to commercial services & + & & & & \\
\hline & demographic conditions & + & + & + & + & + \\
\hline \multirow[t]{7}{*}{ environmental } & distance from residential areas & + & + & + & + & + \\
\hline & distance from agricultural land & & & & & + \\
\hline & $\begin{array}{l}\text { distance from the valuable natural } \\
\text { areas }\end{array}$ & + & & & & + \\
\hline & air pollution / dust, gases & + & & & & + \\
\hline & soil pollution & & & & & + \\
\hline & water pollution & & & & & + \\
\hline & noise & + & & & & \\
\hline
\end{tabular}

Key: investments of a residential character - R; commercial character - C; public utility buildings - PS; communication infrastructure - CI; investments of an industrial nature - I;

\section{Source: own research.}

The information contained in Table 1 shows that the MSIP for the city of Krakow provides a full range of data necessary for decision-making processes concerning the location of investments. Using the data contained in the MSIP, the ratio of the suitability of the site (Siejka, 2015) for the location of a housing estate was calculated. Research was conducted among 10 developers operating in Cracow, who indicated the factors determining the choice of potential locations of housing estates. All the factors indicated by the respondents have been summarized in Table 2 . The study area includes the south-western part of Krakow in the land registry unit Podgórze. A point grid was created in the study area. In each point grid data were collected in the form of the factors $\left(x_{i}\right)$ referred to in Table 2.

Factors concerning the location of the housing estate

Table 2

\begin{tabular}{|c|c|c|}
\hline $\begin{array}{c}\text { Group of factors } \\
\mathbf{K}\end{array}$ & $\begin{array}{c}\text { Type of factor } \\
\mathbf{P}\end{array}$ & Description of factor \\
\hline \multirow{4}{*}{$\begin{array}{l}\text { Legal - Technical } \\
\qquad \text { K1 }\end{array}$} & $\begin{array}{l}\text { Designation of the area } \\
\text { P1 }\end{array}$ & spatial development plan, decision on building conditions \\
\hline & $\begin{array}{l}\text { technical infrastructure } \\
\text { P2 }\end{array}$ & $\begin{array}{l}\text { the distance from the technical infrastructure network } \\
\text { expressed in meters, }\end{array}$ \\
\hline & $\begin{array}{l}\text { access } \\
\text { P3 }\end{array}$ & distance from main public roads expressed in meters \\
\hline & $\begin{array}{l}\text { public transport } \\
\text { P4 }\end{array}$ & distance from public transport stops, expressed in meters \\
\hline \multirow{5}{*}{$\begin{array}{l}\text { Economic and Social } \\
\qquad \mathrm{K} 2\end{array}$} & $\begin{array}{l}\text { transaction prices of land } \\
\text { P5 }\end{array}$ & average price of land per transaction $\left[\mathrm{PLN} / \mathrm{m}^{2}\right]$ \\
\hline & $\begin{array}{l}\text { transaction prices of } \\
\text { residential premises } \\
\text { P6 }\end{array}$ & $\begin{array}{l}\text { average unit transaction price of residential units in the } \\
\text { primary market }\left[\mathrm{PLN} / \mathrm{m}^{2}\right]\end{array}$ \\
\hline & $\begin{array}{l}\text { distance from public/ } \\
\text { societal/ social services } \\
\text { P7 }\end{array}$ & $\begin{array}{l}\text { distance from the school / nursery / health center and } \\
\text { others expressed in meters }\end{array}$ \\
\hline & $\begin{array}{l}\text { distance from commercial } \\
\text { properties } \\
\text { P8 }\end{array}$ & distance from the shopping center, expressed in meters \\
\hline & $\begin{array}{l}\text { demographic conditions } \\
\text { P9 }\end{array}$ & $\begin{array}{l}\text { population density in a given area - the number of persons } \\
\text { / ha }\end{array}$ \\
\hline \multirow{3}{*}{$\begin{array}{l}\text { Environmental } \\
\qquad \mathrm{K} 3\end{array}$} & $\begin{array}{l}\text { distance from residential } \\
\text { areas } \\
\text { P11 }\end{array}$ & distance from residential areas, expressed in meters \\
\hline & $\begin{array}{l}\text { distance from green areas } \\
\text { P11 }\end{array}$ & distance from green areas expressed in meters \\
\hline & $\begin{array}{l}\text { noise } \\
\text { P12 }\end{array}$ & noise level $[\mathrm{dB}]$ \\
\hline
\end{tabular}




\section{Source: own elaboration.}

Values of collected factors are expressed in different units. Standardization of their values was carried out in order to use them in the analysis. Linear standardization was applied according to the following formulae:

when factors mean benefits

$$
w_{i}=\frac{x_{i}}{\max x_{i}}
$$

$$
w_{i}=1-\frac{x_{i}}{\max x_{i}}
$$

when factors mean losses. At each point of the grid, the value of the usefulness factor of the site $\overline{\bar{\gamma}}_{\overline{7}}$ was calculated according to the formula:

$$
W_{p t}=\sum_{i=1}^{n} k_{i} w_{i}
$$

where: $i=1,2,3, \ldots, n$; $k$-weight factor.

Values between nodes of the grid are interpolated using bilinear interpolation, according to the algorithm shown in Figure 4.

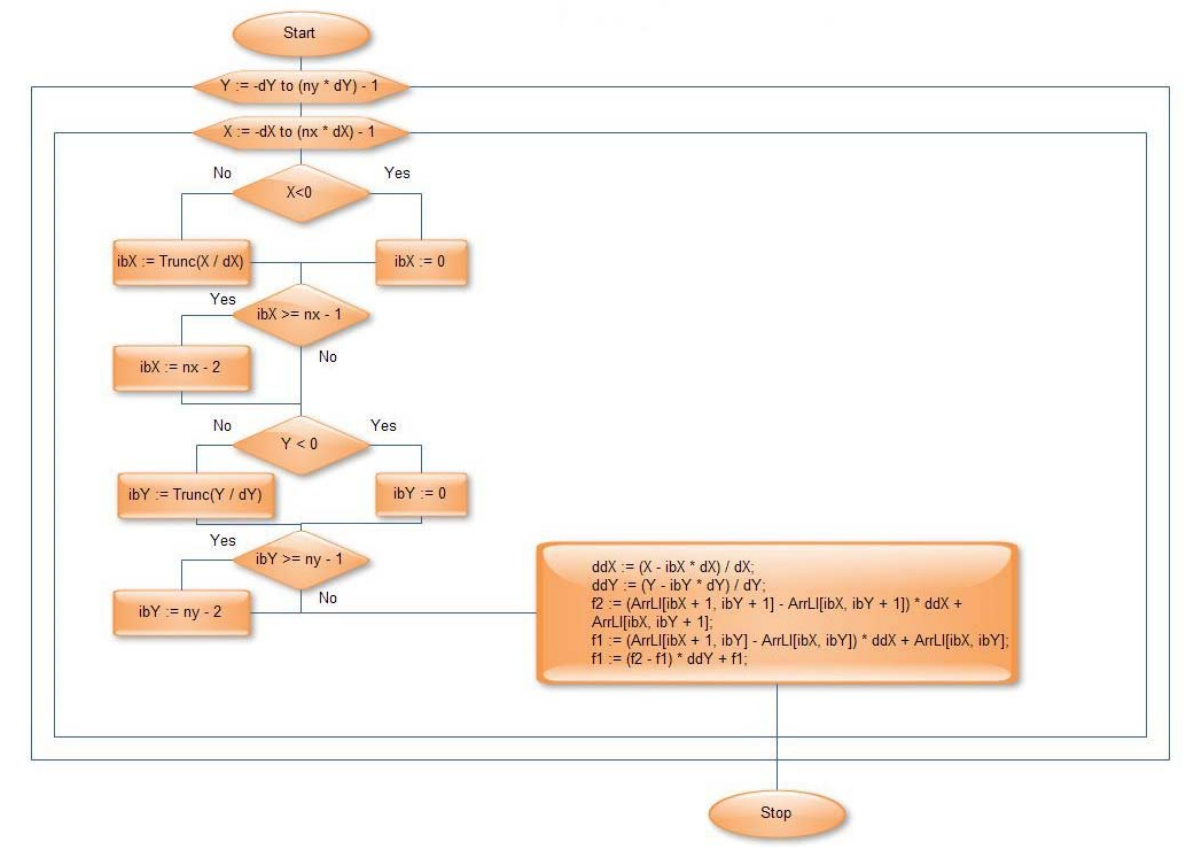

Fig. 4. Algorithm of bilinear interpolation. Source: own study.

Weight factors are calculated using the method of analytical hierarchy process (AHP) (Formula 4). AHP is one of the methods of solving multi-criteria decision-making tasks. Currently, this method is increasingly used in many fields of science, as well as in the implementation of practical tasks. The most common application is for forecasting and planning in engineering, real estate management, economics, and administration and management, at the local as well as central levels (Saaty 1980; Saaty 2000; Hamalainen et. al. 2000; Petts 2000; Mardle et. al., 2004; Sirikijpanichkul, Ferreira 2005; Rao 2007; Wu, Chen 2007; Yoxas et. al. 2011; Salo, Hämäläinen 2012; Zelenovic'-Vasiljevic' et. al. 2012; Siejka, 2015).

Weights of individual factors were calculated according to the formula:

where:

$$
\boldsymbol{C}[1, k]^{T}=\prod_{i=2}^{k} \boldsymbol{B}_{i}=\boldsymbol{B}_{k} \cdot \boldsymbol{B}_{k-1} \ldots \boldsymbol{B}_{2}
$$


$C[1, k]$ - The vector of resulting weight parameters for criteria associated with elements of hierarchical level $k$, in relation to the objective, which is the first level,

$\boldsymbol{B}_{\boldsymbol{i}}$ - matrix of level "i" where columns are vectors of the priority of elements of this level in relation to the elements of level $i-1$.

The research work carried out in this study was performed with the use of a proprietary solution concerning the development of a method for indicating potentially the best investment location along with the proprietary application LandRange, developed in Delphi environment. As a reference basis, the publicly available GoogleMaps service was used. The application displays the results on the area indicated in Google Maps covered by the analysis, in the form of the spatial distribution of the factor value of the usefulness of land for the implementation of the assumed objective. The usefulness of the site is visualized by the mask of color (Fig. 5). The application using the extrapolation method predicts the suitability of the area outside of the established area covered by the analysis, within a strip the width of one side of the inner interpolation grid.

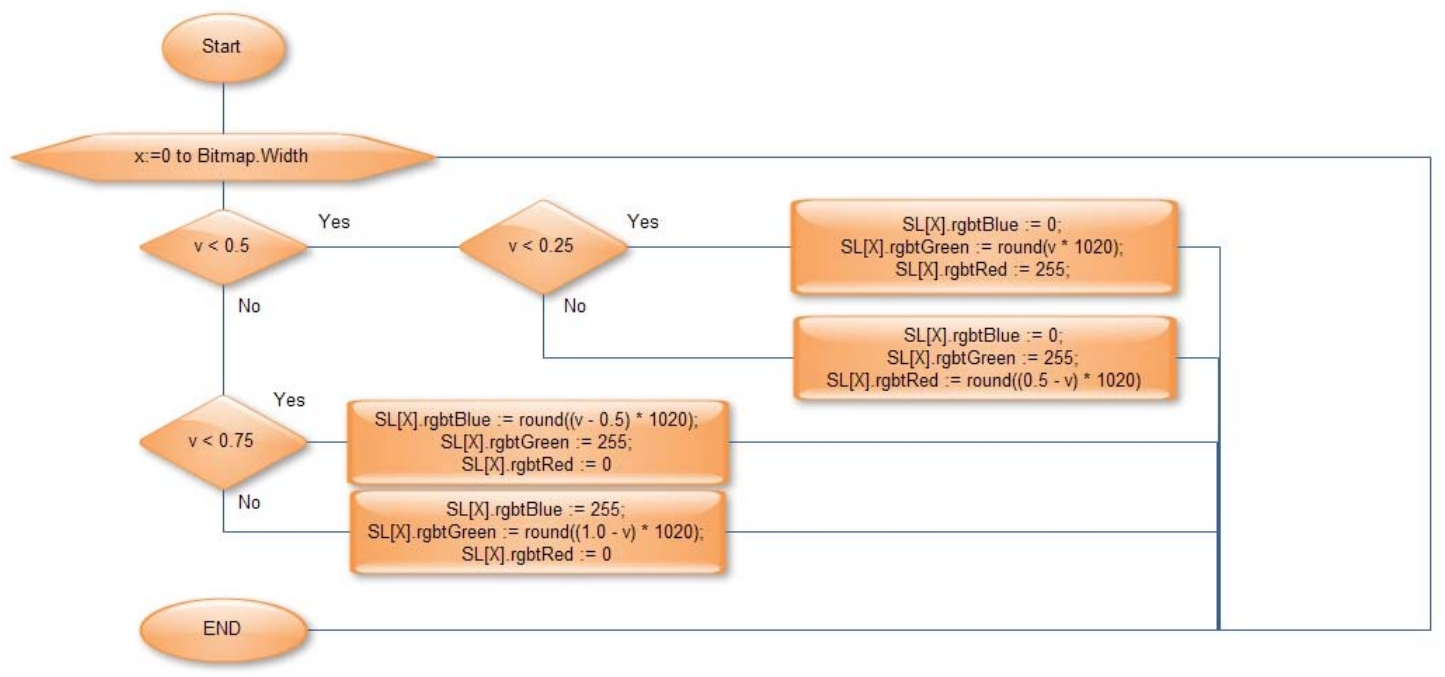

Fig. 5. Algorithm of color gradient. Source: own study.

The developed application can be used to determine, within the study area, locations with different levels of usefulness for the realization of a specified investment, which is a starting point for discussing environmental issues. It also allows sites the usefulness of which has been determined to be at a level lower than indicated by the decision-maker to be excluded from the analysis.

\section{Research results}

The factors listed in Table 3 were evaluated in terms of their impact on the outcome of the analysis. The weight of each factor was calculated using the AHP method. Figure 6 shows a diagram of the hierarchy. The general objective is on the first level; the second level contains groups of factors, while the third level contains all factors identified in the survey as relevant from the point of view of analysis.

This structure was the basis for the creation of the matrix of pairwise comparisons for each level. For each matrix, the eigenvalue was calculated, the assessment of compliance was carried out, and the vector of priorities was calculated as a normalized eigenvector for maximum real eigenvalue. The results of these calculations have been shown in tables 3-6.

Table 3

Calculation results for the first level

\begin{tabular}{|c|c|c|c|c|c|}
\hline \multicolumn{2}{|l|}{ Group of factors } & K1 & K2 & K3 & Priority \\
\hline Legal - Technical & K1 & 1.00 & 0.30 & 0.30 & 12 \\
\hline Economic and Social & K2 & 4.00 & 1.00 & 0.50 & 36 \\
\hline Environmental & K3 & 3.00 & 2.00 & 1.00 & 52 \\
\hline \multicolumn{2}{|c|}{ Compliance assessment } & & & & \\
\hline $\mathrm{CI}<0.1$ & 0.043 & & & & \\
\hline$C R<0.1$ & 0.074 & & & & \\
\hline
\end{tabular}




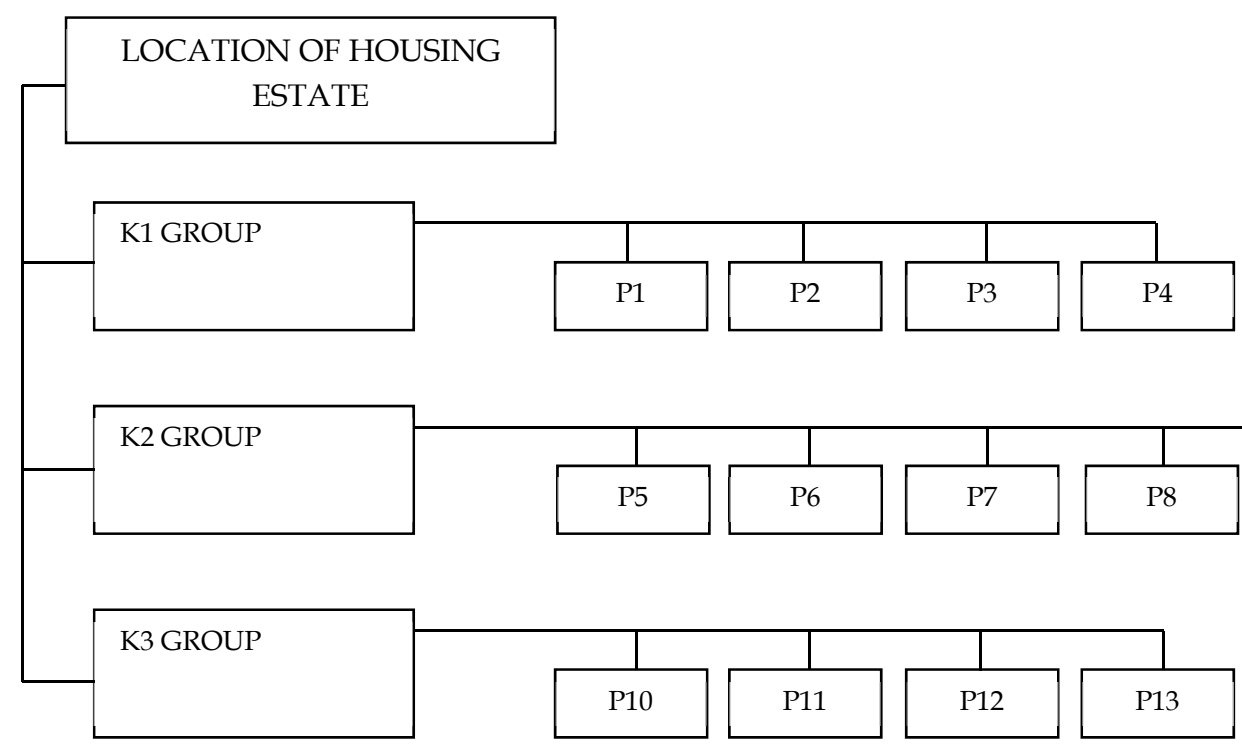

Fig. 6. Schematic structure of the hierarchy - the location of the housing estate. Source: own research.

The calculation results for the second level K1P

Table 4

\begin{tabular}{|c|c|c|c|c|c|c|}
\hline Group of factors & & K1P1 & K1P2 & K1P3 & K1P4 & Priority \\
\hline designation of the area & K1P1 & 1.00 & 7.00 & 5.00 & 5.00 & 8 \\
\hline technical infrastructure & K1P2 & 0.14 & 1.00 & 3.00 & 3.00 & 2 \\
\hline access & K1P3 & 0.20 & 0.33 & 1.00 & 0.50 & 1 \\
\hline public transport & K1P4 & 0.20 & 0.33 & 2.00 & 1.00 & 1 \\
\hline \multicolumn{7}{|l|}{ Compliance assessment } \\
\hline $\mathrm{CI}<0.1$ & 0.071 & & & & & \\
\hline $\mathrm{CR}<0.1$ & 0.079 & & & & & \\
\hline
\end{tabular}

Source: own research.

Calculation results for the second level K2P

Table 5

\begin{tabular}{|c|c|c|c|c|c|c|c|}
\hline Group & & K2P5 & K2P6 & K2P7 & K2P8 & K2P9 & Priority \\
\hline transaction prices of land & K2P5 & 1.00 & 4.00 & 0.20 & 4.00 & 0.33 & 5 \\
\hline $\begin{array}{ll}\text { transaction prices } & \text { of } \\
\text { residential premises } & \end{array}$ & K2P6 & 0.25 & 1.00 & 0.20 & 3.00 & 0.14 & 2 \\
\hline $\begin{array}{l}\text { distance from public/ } \\
\text { societal/social services }\end{array}$ & K2P7 & 5.00 & 5.00 & 1.00 & 7.00 & 3.00 & 17 \\
\hline $\begin{array}{l}\text { distance from commercial } \\
\text { properties }\end{array}$ & K2P8 & 0.25 & 0.33 & 0.14 & 1.00 & 0.14 & 1 \\
\hline demographic conditions & K2P9 & 3.00 & 7.14 & 0.33 & 7.14 & 1.00 & 11 \\
\hline \multicolumn{8}{|l|}{ Compliance assessment } \\
\hline $\mathrm{CI}<0.1$ & 0.076 & & & & & & \\
\hline $\mathrm{CR}<0.1$ & 0.068 & & & & & & \\
\hline
\end{tabular}

Source: own research.

Calculation results for the second level K3P

Table 6

\section{Calculation results for the second level K3P}

\begin{tabular}{|c|c|c|c|c|c|c|}
\hline \multicolumn{2}{|l|}{ Group } & K3P10 & K3P11 & K3P12 & K3P13 & Priority \\
\hline $\begin{array}{lll}\text { distance from } & \text { residential } \\
\text { areas } & & \\
\end{array}$ & K3P10 & 1.00 & 0.30 & 7.00 & 3.00 & 16 \\
\hline distance from the green areas & K3P11 & 3.33 & 1.00 & 3.00 & 3.00 & 26 \\
\hline noise & K3P12 & 0.14 & 0.33 & 1.00 & 0.50 & 4 \\
\hline air pollution / dust, gases & K3P13 & 0.33 & 0.33 & 2.00 & 1.00 & 6 \\
\hline \multicolumn{2}{|l|}{ Compliance assessment } & & & & & \\
\hline $\mathrm{CI}<0.1$ & 0.082 & & & & & \\
\hline$C R<0.1$ & 0.091 & & & & & \\
\hline
\end{tabular}

Source: own research. 
Empirical studies have shown that, among groups of factors, the dominant role is played by the group of environmental factors (52\%), then the group of socio-economic factors (36\%), with the lowest weight for the group of legal and technical factors $(12 \%)$. The distribution of weights in each group, however, is different. The following factors are characterized by the highest weights: the distance from green areas $(26 \%)$, the distance from public services $(17 \%)$, the distance from housing areas $(16 \%)$, population density $(11 \%)$, and the use of the land in the spatial development plan $(8 \%)$. Other factors possessed weights below $8 \%$.

Weights of factors calculated using the AHP method were included in the LandRange application algorithm. The results of the analysis in the form of the distribution of values of the usefulness factors of the site for the location of residential estate in the study area have been shown in Figure 7. For the analyzed area, the factor value is in the range from 18.4 to 73.4. The distribution of the factor within the given interval is shown by the mask of colors. The largest areas of maximum or nearmaximum values are located in the central and south-western part of the studied area. These areas are potentially the best location for housing development in the study area.

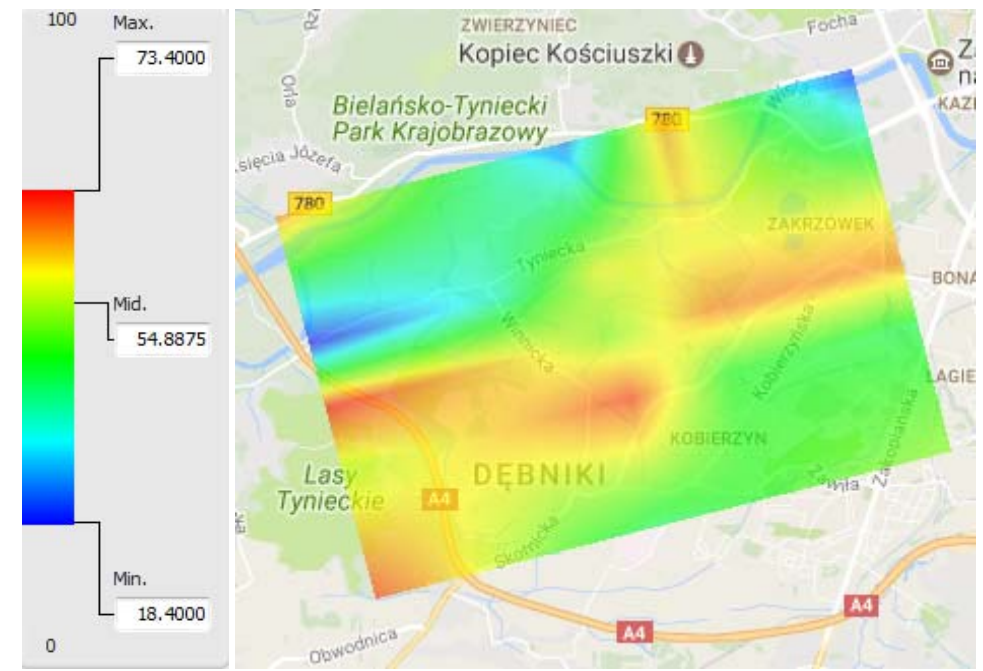

Fig. 7. Distribution of values of land usefulness in the analyzed area. Source: own research.

Figure 8 shows the areas in which the value of the usefulness of the site is above the mean value. In total, the area accounts for about $45 \%$ of the area covered by the analysis. The developed method of calculating the usefulness of a given site to the completion of an investment project makes it possible to disqualify areas in which the factor is lower than the value expected (established) by the person conducting the analysis.

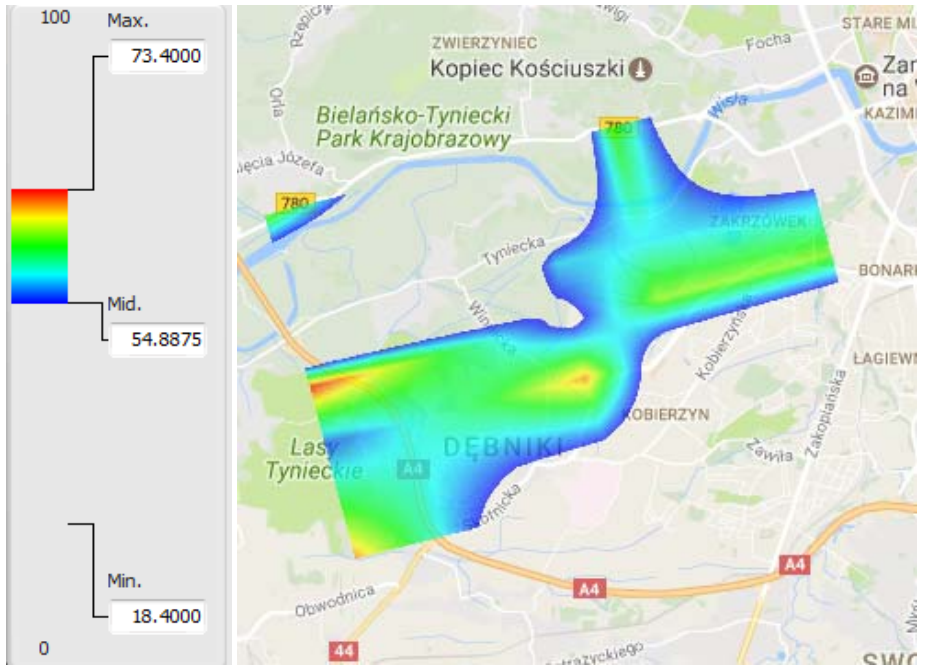

Fig. 8. Area in which the usefulness value is above the average. Source: own research. 


\section{Conclusions}

Decisions concerning the location of investments undertaken by the government administration, at different levels, have a significant impact on the economy if a region. They can contribute to an increase or inhibit its development. To avoid or at least minimize the negative impact of investment decisions, they should be taken on the basis of previously conducted analyses. Analyses of decisions concerning the location of investments require the consideration of a number of factors defining the terms of their location, and the effects of their impact on people and the environment.

The solution for calculating the usefulness of land for the location of a given investment proposed in the work is effective only when the person carrying out the analysis has access to full and reliable information. As follows from the study for the area of the city of Krakow, mapping services available within the ISI contain complete data necessary to carry out studies on the indication of the suitability of an investment location. Using the local spatial information system, all factors identified by the surveyed developers as important to carrying out this analysis were acquired.

Therefore, information systems play a key role in the decision-making processes concerning the location of investments. High quality and unlimited access to data collected therein increases the accuracy of the results of decision-making analyses.

\section{References}

Bieda A., BydŁosz J., Dawid L., DAwidowicz A., Glanowska A., Góźdź K., PrZewięźLIKowska A., STUPEN M., RATATULA R., ŹRÓBEK, R., 2015, Kierunki rozwoju katastru nieruchomości, (Trends in the Development of the Real Estate Cadastre), Monografia, Bieda A., (red.), Rzeszow: WSIE.

Dawidowicz A., RADZEWicz A., Renigier-BiŁOZOR M., 2014, Algorithm for Purposes of Determining Real Estate Markets Efficiency with Help of Land Administration System, Survey Review, Vol. 46 (336), 189-204.

Directive 2007/2/EC of the European Parliament and of the Council of 14 March 2007 establishing an Infrastructure for Spatial Information in the European Community (INSPIRE) http://eurlex.europa.eu/LexUriServ/LexUriServ.do?uri=OJ:L:2007:108: 0001.

Hamalainen R. P., Lindstedt M. R., SinKKO K., 2000, Multiattribute Risk Analysis in Nuclear Emergency Management, Risk Analysis An International Journal, 20(4), 455-467.

MARdLE S., PAscoe S., HerRero I., 2004, Management Objective Importance in Fisheries: an Evaluation using the Analytic Hierarchy Process (AHP), Environmental Management, 33(1), 1-11.

PETTS J., 2000, Municipal Waste Management: Inequities and the Role of Deliberation, Risk Analysis An International Journal, 20 (6), 821-832.

RAO R. V., 2007, Decision Making in the Manufacturing Environment Using Graph Theory and Fuzzy Multiple Attribute Decision Making Methods, London: Springer-Verlag.

SAATY T. L., 1980, The Analytical Hierarchy Process, New York: McGraw-Hill, International Book Company.

SAATY T. L., 2000, Fundamentals of Decision Making and Priority Theory with the AHP, Pittsburg: RWS.

SAlO, A., HÄMÄLÄINEN, R. P., 2012, Multicriteria Decision Analysis in Group Decision Processes. W: Kilgour D. M., Eden C. (red.), Handbook of Group Decision and Negotiation, Dordrecht, Springer, pp. 269-284.

SIEJKA M., Optymalny wybór lokalizacji inwestycji w gospodarce nieruchomościami, (Optimal Selection of Investment Location in Land Management), Polish Academy of Sciences, Infrastructure and ecology of rural areas, IV/2, Krakow, 2015.

SIEJKA M. 2016. Public Purpose Investmments Site Selection in Real Estate Management - Case Study in Poland, 16th International Multidisciplinary Scientific GeoConference SGEM 2016, www.sgem.org, SGEM2016 Conference Proceedings, ISBN 978-619-7105-59-9 / ISSN 1314-2704, June 28 - July 6, 2016, Book2 Vol. 2, 503-510 pp. DOI: 10.5593/SGEM2016/B22/S09.065.

Ustawa o infrastrukturze informacji przestrzennej z dnia 4 marca 2010 r., (Act on Infrastructure for Spatial Information) Dz.U.Nr 76, poz. 489 z późn. zm. (Journal of Laws No. 76 item 489 as amended) http://isap.sejm.gov.pl/ DetailsServlet?id=WDU20100760489, (access 10.01.2017).

SIRIKIJPANICHKUl A., FERREIRA L., 2005, Multi-Objective Evaluation of Intermodal Freight Terminal Location Decisions, Proceedings of the 27th Conference of Australian Institute of Transport Research (CAITR), Queensland University of Technology, 7-9 December 2005. 
WilKOWSKi W., BUdZYŃSKI T., SOBOlEWSKA-MiKUlSKA K., PUŁECKA A., 2006, Wspótczesne problemy katastru i gospodarki nieruchomościami, (Contemporary Problems of Cadastre and Real Estate Management). Warszawa: PW.

Wu, Z., CHEN, Y., 2007, The Maximizing Deviation Method for Group Multiple Attribute Decision Making under Linguistic Environment, Fuzzy Sets and Systems, 158(14), 1608-1617.

Yoxas G., SAMARa T., SARgologou L., Stournaras G., 2011, Multiple Criteria Analysis for Selecting Suitable Sites for Construction of Sanitary Landfill Based on Hydrogeological Data; Case Study of Kea Island (Aegean Sea, Hellas), Advances in the Research of Aquatic Environment, 2, 97-104, DOI 10.1007/978-3-642-24076-8.

ZELENOVIC'-VASILJEVIC' T., SRDJEVIC' Z., BAJC'ETIC' R., VojINOVIC'-MiloradOV M., 2012, GIS and the Analytic Hierarchy Process for Regional Landfill Site Selection in Transitional Countries: A Case Study from Serbia, Environmental Management, 49, 445-458. DOI 10.1007/s00267-011-9792-3. 